\title{
Korelasi Signifikan antara Kecepatan Superfisial dan Viskositas Cairan Menggunakan Pola Aliran Dua Fase pada Pipa Mini dengan Kemiringan $30^{\circ}$
}

\author{
Sukamta ${ }^{1}$, Sudarja ${ }^{2}$ \\ Program Studi Teknik Mesin, Fakultas Teknik, Universitas Muhammadiyah Yogyakarta \\ Jl. Brawijaya, Geblagan, Tamatirto, Kasihan, Bantul, Daerah Istimewa Yogyakarta, \\ Indonesia \\ Email:sukamta@umy.ac.id'1, sudarja@umy.ac.id²
}

\begin{abstract}
This paper present a novel result of significant correlation between superficial velocity and viscosity on two-phase flow pattern in mini channel with slope of $30^{\circ}$ against horizontal. This research used glass mini pipe $1.6 \mathrm{~mm}$ diameter and $130 \mathrm{~mm}$ length with a slope of $30^{\circ}$ to the horizontal position. The working fluid used is air - water with glycerin of $40 \%, 50 \%, 60$ $\%, 70 \%$ concentration. Liquid superficial velocity $J_{L}=0.033-4.935 \mathrm{~m} / \mathrm{s}$ and gas superficial velocity $J_{G}=0.025-66.3 \mathrm{~m} / \mathrm{s}$. High-speed Camera was used to visualize the flow pattern. Summing up the result, it can be concluded that gas/water superficial velocity and viscosity of liquid effected significantly to form a flow patterns. In this paper, flow pattern of plug, bubbly, slug annular, annular, and churn were successfully found. Flow pattern maps showed that the distribution of different flow patterns due to the increased viscosity. Comparing with previous studies showed that there is a good agreement result.
\end{abstract}

Keywords: high-speed, superficial velocity, viscosity, flow pattern

\begin{abstract}
Abstrak
Makalah ini menyajikan hasil baru dari korelasi yang signifikan antara kecepatan superfisial dan viskositas pada pola aliran dua fase dalam saluran mini dengan kemiringan $30^{\circ}$. Penelitian ini menggunakan pipa kaca mini berdiameter 1,6 $\mathrm{mm}$ dan panjang $130 \mathrm{~mm}$ dengan kemiringan $30^{\circ}$. Fluida yang digunakan adalah udara-air gliserin dengan konsentrasi $40 \%$, $50 \%, 60 \%, 70 \%$. Kecepatan superfisial cair $\mathrm{JL}=0,033-4,935 \mathrm{~m} / \mathrm{s}$ dan kecepatan dangkal gas $\mathrm{JG}=0,025-66,3 \mathrm{~m} / \mathrm{s}$. Kamera berkecepatan tinggi digunakan untuk memvisualisasikan pola aliran. Hasilnya, dapat disimpulkan bahwa kecepatan superfisial gas/air dan viskositas cairan berpengaruh secara signifikan untuk membentuk pola aliran. Dalam makalah ini, pola aliran plug, bubbly, slug annular, annular, dan churn berhasil ditemukan. Peta pola aliran menunjukkan bahwa distribusi pola aliran berbeda karena peningkatan viskositas. Dibandingkan dengan penelitian sebelumnya menunjukkan bahwa ada kesesuaian hasil.
\end{abstract}

Kata kunci: kecepatan tinggi, kecepatan superfisial, viskositas, pola aliran.

\section{Pendahuluan}

Aliran dua fase (khususnya pada saluran mini) masih sangat luas pengaplikasiannya khususnya pada dunia industri maupun dalam kehidupan manusia sehari-harinya. Aplikasi aliran dua fase pada pipa mini antara lain micro-electromechanical-system (MEMS) dan sistem pendinginan mikroelektronik (microelectronic cooling system). Di dalam kehidupan sehari-hari manusia aliran dua fase atau lebih tepatnya aliran banyak komponen pada saluran mini diaplikasikan secara alamiah yaitu pada sistem peredaran darah manusia, dimana darah yang mengandung oksigen, karbohidrat, protein (dalam bentuk asam amino) serta nutrisi yang didapat dari makanan dialirkan melalui pembuluh darah yang kemudian diedarkan ke seluruh tubuh. 
Dalam suatu studi aliran dua fase hal yang sangat penting untuk dipelajari adalah tentang pola aliran. Pola aliran ini menjadi suatu poin penting dikarenakan adanya penggabungan karateristik yang berbeda antar fase yang bergabung dalam suatu saluran. Dalam penelitiannya Fukano dan Kariyasaki (1993) menyatakan bahwa pada saluran mini maka gravitasi tidak mempengaruhi pola aliran [1]. Artikel ini mempresentasikan tentang hubungan antara kecepatan superfisial dan viskositas terhadap pola aliran. Namun demikian, disingggung pula tentang pengaruh sudut kemiringan terhadap pola aliran. Penelitan mengenai aliran dua fase pada pipa kecil dan sedang sudah sering dilakukan, tetapi pada pipa dengan saluran mini (minichannel) dan pipa mikro (microchannel) masih sedikit. Ada beberapa penelitian yang pernah dilakukan pada pipa saluran mini dan mikro yaitu Fukano dkk. (1993), Triplet dkk. (1999), Serizawa dkk. (2002), Kawahara dkk.(2002), Chung dan Kawaji (2004), dan Wegman dkk. (2007).

Dalam penelitian aliran dua fase pada saluran mini dan mikro pengaruh dari gravitasi diabaikan, dianggap tidak berpengaruh pada aliran. Pola aliran yang terbentuk hanya dipengaruhi oleh viskositas, kecepatan superfisial cair dan gas, tegangan permukaan fluida cair. Peta pola aliran yang dihasilkan pada pipa mini dan mikro akan berbeda dengan pola dan peta pola aliran pada pipa konvensional. Pola dan peta pola aliran menjadi parameter penting untuk menunjukan karakteristik dari aliran dua fase. Penelitian tersebut dilakukan menggunakan tiga ukuran diameter pipa sirkular masing-masing 1 $\mathrm{mm}, 2,4 \mathrm{~mm}$, dan $4,9 \mathrm{~mm}$. Media yang digunakan yaitu fase cair menggunakan air, sedangkan untuk fase gasnya menggunakan udara, untuk arah alirannya divariasikan menjadi tiga arah yaitu arah horizontal, vertikal ke bawah dan vertikal ke atas. Secara umum pada penelitian ini, pola aliran yang terbentuk diklasifikasikan menjadi tiga, yaitu aliran bubble, aliran intermittent dan aliran annular [2].

Serizawa dkk. (2002) [3]

melakukan penelitian aliran dua fase menggunakan pipa silika dan kuarsa dengan arah horizontal menggunakan empat variasi diameter yaitu 20,25, 50, dan $100 \mu \mathrm{m}$. Udara dan uap air digunakan sebagai fase gas sedangkan untuk fase cair menggunakan air. Variasi untuk kecepatan superfisial gas berkisar antara 0,0012$295,3 \mathrm{~m} / \mathrm{s}$ dan kecepatan superfisial cairan mulai dari 0,003-7,52 m/s. Dari hasil visualisasi penelitian ini didapat jenis aliran langka yang dapat dijelaskan karakteristik serta dapat divisualisasikan dengan baik menggunakan fotografi. Pola aliran yang di dapat diantaranya yaitu : dispersed bubbly, gas slug, liquid ring, liquid pump, annular, frothy, wishphy-annular, rivulet, liquid drplet bubbly, dan droplet. Selanjutnya, penelitian aliran dua fase dilakukan oleh Kawahara dkk. (2002) [4] menggunakan fase nitrogen-air yang sudah terionisasi menggunakan saluran sirkular yang terbuat dari fused silica dengan diameter $100 \mu \mathrm{m}$. Kecepatan superfisial udara yang digunakan $0,1-60 \mathrm{~m} / \mathrm{s}$ sedangkan untuk kecepetan superfisial airnya $0,002-4 \mathrm{~m} / \mathrm{s}$. Pola aliran yang berhasil diamati pada penelitian ini adalah aliran liquid alone (liquid slug), gas core with smooth-thin liquid film, gas core with smooth-thick liquid film, gas core with a ring-shaped liquid film, dan agas core with deformed interface. Sementara aliran bubbly dan churn pada penelitian ini tidak teramati karena saluran yang sangat kecil yang berakibat memperkecil nilai bilangan Reynolds, memperbesar tegangan permukaan.

Efek diameter pada aliran dua fase diinvestigasi oleh Chung dan Kawaji (2004) [5] untuk mengidentifikasi fenomena yang membedakan microchannel dari minichannel. Penelitian dilakukan dengan menggunakan gas nitrogen dan air pada saluran berdiameter 530, 250, 100, dan $50 \mu \mathrm{m}$. Pada pipa berdiameter $530 \mu \mathrm{m}$ dan $250 \mu \mathrm{m}$, karakteristik aliran dua fase 
(peta pola aliran, fraksi hampa, pressure drop) mirip dengan karakteristik aliran pada minichannel (diameter $\sim 1 \mathrm{~mm}$ ). Kecepatan superfisial fase cair diatur mulai $0,01-5,77 \mathrm{~m} / \mathrm{s}$ sementara fase gas pada rentang 0,02-72,98 $\mathrm{m} / \mathrm{s}$. Dalam penelitian ini dilakukan visualisasi dengan fotografi terhadap pola aliran yang terbentuk. Hasil eksperimen menunjukan bahwa pipa dengan ukuran 530 dan $250 \mu \mathrm{m}$ memiliki karakteristik berbeda dengan pipa dengan ukuran 100 dan $50 \mu \mathrm{m}$. Pada pipa berdiameter 100 dan $50 \mu \mathrm{m}$, karakteristik aliran menyimpang dari karakteristik pada minichannel, yaitu terjadinya dominasi dari aliran slug. Pola aliran bubbly, churn, slugannular, dan annular pada saluran dengan $\mathrm{DH}<100 \mu \mathrm{m}$ disebabkan karena viskositas dan tegangan permukaan yang lebih besar. Jadi, jelas bahwa pengaruh diameter pipa yang diinvestigasi, memberikan pengaruh pada karakteristik aliran dua fase. Pada tahun berikutnya, dilakukan penelitian aliran dua fase dengan fase cair digunakan air dan parafin, sedangkan untuk fase gas digunakan udara sehingga membentuk aliran air-udara dan paraffin-udara. Penelitian ini menggunakan dua variasi ukuran diameter pipa yaitu 5,6 $\mathrm{mm}$ dan 7 $\mathrm{mm}$. Dengan dua jenis variasi diameter ini didapat perbedaan pola aliran yang terbentuk. Pada pipa dengan diameter 5,6 $\mathrm{mm}$ secara garis besar pola aliran yang diperoleh adalah aliran intermittent dan annular, sedangkan untuk aliran stratified sama sekali tidak ditemukan baik pada aliran air-udara maupun paraffin-udara. Aliran stratified ditemukan pada pipa diameter $7 \mathrm{~mm}$ yaitu pada saat kecepatan superfisial air $0,003 \mathrm{~m} / \mathrm{s}$ dan paraffin 0,06 $\mathrm{m} / \mathrm{s}$ hal ini disebabkan tegangan permukaan air lebih tinggi dibandingkan dengan tegangan permukaan paraffin [6].

Biksono (2006) [7] melakukan penelitian pada pipa spiral untuk mengetahui karakteristik dan visualisasi aliran dua fase. Pengujian menggunakan media air dan udara bertekanan pada pipa dengan diameter luar $52 \mathrm{~mm}$, diameter dalam $27 \mathrm{~mm}$, serta Panjang $1120 \mathrm{~mm}$.
Hasil penelitian menunjukan nilai koefisien gesek pada aliran dua fase lebih besar, serta kecepatan aliran transisi jauh lebih cepat aliran dua fase jika dibandingkan dengan aliran satu fase dengan nilai (1600-1700) pada bilangan Reynold ( $\mathrm{R} e$ ). Besarnya nilai koefisien gesek terjadi karena adanya penambahan variasi kecepatan udara. Sementara itu, Sudarja dkk. (2016) [8] melakukan penelitian tentang pola aliran di dalam pipa berukuran mini pada aliran horizontal. Penelitian ini dilakukan pada seksi uji berupa pipa kaca berdiameter dalam 1,6 $\mathrm{mm}$ posisi horizontal menggunakan fluida gas dan cairan berupa udara kering dan air. Kecepatan superfisial gas yaitu $0,08-64,42 \mathrm{~m} / \mathrm{s}$ dan kecepatan superfisial cairan yaitu $0,02-3,09 \mathrm{~m} / \mathrm{s}$. penelitian ini dilakukan pada suatu instalasi alat yang terdiri dari: tangki air, pompa air, planum, kompresor udara, water trap. Hasil dari penelitian ini didapat peta pola aliran dan pola aliran yang terdeteksi yaitu bubbly, slug, churn, slug-annular, wavyannular dan annular.

Wibowo dkk. (2015) [9] melakukan penelitian pada pipa acrylic berdiameter 26 mm serta panjang $10 \mathrm{~m}$, untuk mengamati visualisasi pola aliran stratified serta beda tekanan. Alat yang digunakan untuk mengamati sub-sub pola aliran secara visual adalah dengan kamera video berkecapatan tinggi, sedangkan untuk mengetahui fluktuasi beda tekanan dilakukan pengukuran pressure drop. Dari hasil pengamatan secara visual pola aliran yang berhasil diamati dapat dibagi menjadi sub-sub pola aliran yaitu stratified smooth two dimensional wave, atomization, serta roll wave. Sulitnya pengamatan secara visual terhadap sub-sub pola aliran disebabkan oleh sinyal beda tekanan yang tidak bisa menggambarkan morfologi pola aliran secara langsung. Hal ini yang menjadi kelemahan jika pengamatan visual hanya dilakukan menggunakan fluktuasi beda tekanan. Wiryanta [10] menghasilkan penelitian yang menunjukkan bahwa untuk kecepatan superfisial liquid rendah, maka pola aliran bubbly dari arah vertikal akan 
cenderung bergerak ke atas pada downstream dari elbow pada jarak 2D dari outlet elbow. Sedangkan pada kecepatan superficial liquid yang sangat tinggi, fase gas akan terkonsentrasi pada inner dari elbow akibat adanya tekanan yang tinggi pada outer elbow, sehingga pola aliran yang teramati pada pipa miring adalah slugbubbly flow atau plug-bubbly flow.

Dari beberapa penelitian yang sudah dilakukan mengenai aliran dua fase pada pipa mini dan mikro bahwa gaya gravitasi tidak mempengaruhi pada terbentuknya pola aliran, sedangkan hal yang mempengaruhi adalah kecepatan superfisial, viskositas, dan tegangan permukaan. Pendalaman lebih lanjut mengenai pengaruh viskositas pada aliran dua fase pada pipa saluran mini mikro masih sedikit. Maka dari itu penelitian aliran dua fase saluran mini dengan pengaruh viskositas masih dibutuhkan untuk menambah pengetahuan mengenai karaketristik aliran dua fase.

\section{Metode Penelitian}

Instalasi peralatan yang digunakan dalam penelitian ditunjukan pada Gambar 1, yang terdiri dari komponen utama meliputi: tangki air, pompa air, kompresor udara, bejana bertekanan, test section, water trap, mixer, dan konektor. Peralatan pendukung yang digunakan dalam penelitian, antara lain: optical correction box, kamera, komputer. Alat ukur yang digunakan dalam penelitian, antara lain: flowmeter air, flowmeter udara. Untuk pengambilan gambar/video aliran digunakan kamera berkecepatan tinggi merk Nikon tipe J4, dengan kecepatan 1200 fps dan resolusi 640 x 480 pixel. Kondisi penelitian dianggap adiabatik, kecepatan superfisial gas $\left(\mathrm{J}_{\mathrm{G}}\right)$ dengan interval 0,025 $66,3 \mathrm{~m} / \mathrm{s}$, dan kecepatan superfisial cairan $\left(\mathrm{J}_{\mathrm{L}}\right)$ dengan interval $0,033-4,935 \mathrm{~m} / \mathrm{s}$.

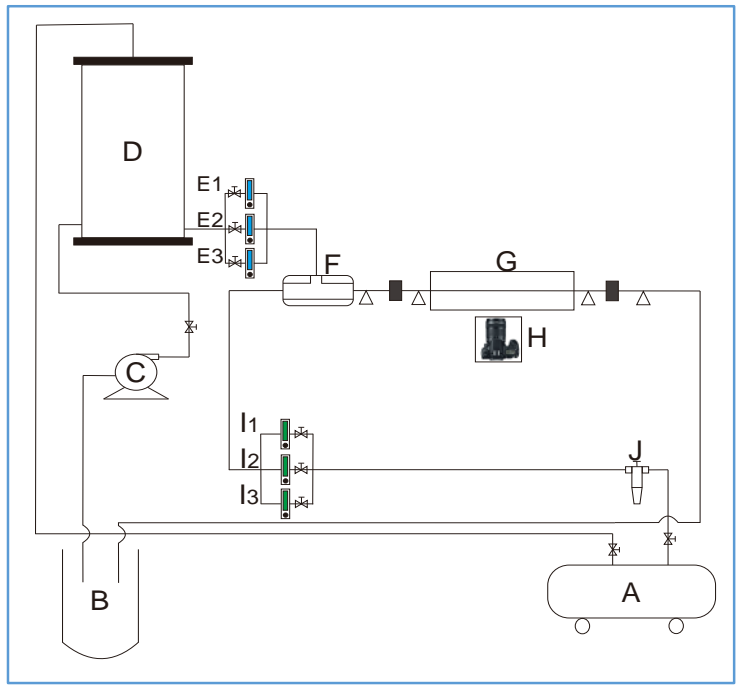

Gambar 1. Skema instalasi penelitian

Keterangan:

A. Kompresor

B. Tempat penampung campuran air dan gliserin

C. Pompa air

D. Bejana bertekanan

E. Flowmeter cair

F. Mixer

G. Seksi uji

H. Kamera

\section{Hasil dan Pembahasan}

Artikel ini mempresentasikan pengaruh kecepatan superfisial gas dan cairan serta viskositas terhadap pola aliran seperti ditunjukkan pada table 1-5 dan gambar 2-4.

Tabel 1. Pola aliran udara-air+gliserin 40$70 \%$ dengan $\mathrm{J}_{\mathrm{G}}=0,025 \mathrm{~m} / \mathrm{s}$ dan $\mathrm{J}_{\mathrm{L}}$

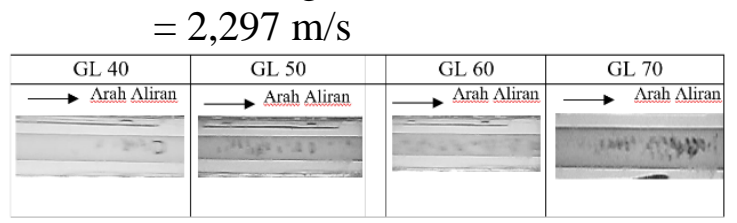

Pengaruh viskositas pada aliran bubbly terlihat jelas yaitu melambatnya kecepatan bubble dengan meningkatnya konsentrasi gliserin pada kecepatan superfisial cairan dan gas yang sama seperti ditunjukkan pada tabel 1. Hal ini disebabkan karena udara yang mendorong cairan semakin mengalami hambatan dengan meningkatnya viskositas cairan yang digunakan. 
Tabel 2. Pola aliran udara-air+gliserin 40$70 \%$ dengan $\mathrm{J}_{\mathrm{G}}=0,025 \mathrm{~m} / \mathrm{s}$ dan $\mathrm{J}_{\mathrm{L}}=0,89 \mathrm{~m} / \mathrm{s}$

\begin{tabular}{|c|c|c|c|}
\hline GL 40 & GL 50 & GL 60 & GL 70 \\
\hline$\longrightarrow$ Arah Aliran & $\longrightarrow$ Arah Aliran & $\longrightarrow$ Arah Aliran & $\longrightarrow$ Arah Aliran \\
\hline$\square$ & $D \longleftarrow$ & $\square \cdot \square \square$ & $D^{\circ} \leftrightharpoons$ \\
\hline
\end{tabular}

Pengaruh kenaikan viskositas cairan pada pola aliran plug yaitu semakin mengecilnya bentuk plug yang terjadi dengan meningkatnya viskositas cairannya seperti diperlihatkan pada tabel 2. Hal ini disebabkan karena gaya kohesivitasnya meningkat dengan meningkatnya viskositas.

Tabel 3. Pola aliran udara-air+gliserin dengan $\mathbf{J}_{\mathrm{G}}=3 \mathrm{~m} / \mathrm{s}$ dan $\mathrm{J}_{\mathrm{L}}=0,091$ $\mathrm{m} / \mathrm{s}$

\begin{tabular}{|c|c|c|c|}
\hline GL 40 & GL 50 & GL 60 & GL 70 \\
\hline$\longrightarrow$ Arah aliran & $\longrightarrow$ Arah aliran & $\longrightarrow$ Arah aliran & $\longrightarrow$ Arah aliran \\
\hline 2 & 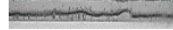 & 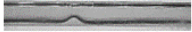 & D \\
\hline
\end{tabular}

Tabel 3 menunjukkan hasil pengamatan terhadap pola aliran slug annular dimana tidak terjadi perbedaan yang signifikan dari pola aliran ini yang disebabkan oleh peningkatan viskositas, hanya ketebalan lapisan cairan bagian bawah jauh lebih tebal dan jauh lebih bergelombang dibandingkan dengan lapisan atas saluran. Ketika viskositas dinaikkan ketebalan lapisan air yang timbul akan semakin menebal pula. Perbedaan konsentrasi gliserin pada pola slug annular, ketika viskositas dinaikkan menunjukan gas inti yang berada di bagian tengah tidak tercekik, hal ini diakibatkan karena cairan memiliki viskositas besar sehingga tidak mudah digerakkan oleh aliran gas/udara. Perbedaan konsentrasi gliserin pada pola slug annular tidak begitu terlihat secara jelas pengaruhnya, tidak ada perbedaan bentuk yang bisa diamati secara detail.

Tabel 4. Pola aliran udara-air+gliserin 40$70 \%$ dengan $\mathrm{J}_{\mathrm{G}}=50 \mathrm{~m} / \mathrm{s}$ dan $\mathrm{J}_{\mathrm{L}}=$ $0,149 \mathrm{~m} / \mathrm{s}$

\begin{tabular}{|c|c|c|c|}
\hline GL 40 & GL 50 & GL 60 & GL 70 \\
\hline$\longrightarrow$ Arah aliran & $\longrightarrow$ Arah aliran & $\longrightarrow$ Arah alıran & $\longrightarrow$ Arah aliran \\
\hline m & - & 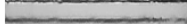 & 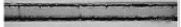 \\
\hline
\end{tabular}

Demikian pula perbandingan pola aliran annular untuk tiap konsentrasi larutan gliserin dengan nilai $\mathrm{J}_{\mathrm{G}}=50 \mathrm{~m} / \mathrm{s}$ dan $\mathrm{J}_{\mathrm{L}}=0,149 \mathrm{~m} / \mathrm{s}$ terlihat pada tabel 4 . Pengaruh kenaikan viskositas pada pola aliran annular terlihat bahwa semakin besarnya viskositas cairan mengakibatkan riak air yang timbul semakin berkurang. Berdasarkan rekaman video terlihat kecepatan aliran lebih lambat terjadi ketika viskositas cairan semakin meningkat secara signifikan.

Tabel 5. Pola aliran udara-air+gliserin dengan $\mathrm{J}_{\mathrm{G}}=22,6 \mathrm{~m} / \mathrm{s}$ dan $\mathrm{J}_{\mathrm{L}}=0,7$ $\mathrm{m} / \mathrm{s}$

\begin{tabular}{|c|c|c|c|}
\hline GL 40 & GL 50 & GL 60 & GL 70 \\
\hline$\longrightarrow$ Arah aliran & $\longrightarrow$ Arah aliran & $\longrightarrow$ Arah aliran & $\longrightarrow$ Arah aliran \\
\hline 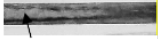 & $\longrightarrow$ & 7 & $\Rightarrow$ \\
\hline Inti gas & Intigas & Inti gas & Inti gas \\
\hline
\end{tabular}

Dari tabel 5 pola aliran churn terlihat seperti plug yang memiliki ekor hancur atau acak yang kemudian diikuti aliran gelembung-gelembung kecil. Inti dari aliran ini memiliki kecepatan yang sangat cepat sesuai dengan nilai $\mathrm{J}_{\mathrm{G}}$ dan $\mathrm{J}_{\mathrm{L}}$ nya. Pada konsentrasi gliserin 40 dan $70 \%$ aliran churn bagian gas yang menyerupai aliran annular terdapat gelembung-gelembung kecil yang melekat dan mengikuti aliran udara pada aliran churn yang muncul. Pengaruh viskositas yang dinaikkan dengan nilai $\mathrm{J}_{\mathrm{G}}$ dan $\mathrm{J}_{\mathrm{L}}$ yang tetap terlihat kecepatan aliran yang timbul lebih lambat daripada viskositas yang lebih rendah.

Meningkatnya viskositas pada peta pola aliran terlihat pada luas garis transisi yang terjadi antar tiap pola aliran dengan konsentrasi gliserin yang berbeda. Pada Gambar 2. Disajikan hasil peta pola aliran udara-air+gliserin dengan konsentrasi $40 \%$, $50 \%, 60 \%$, dan $70 \%$ pada diameter pipa 1,6 mm dan sudut kemiringan pipa $30^{\circ}$. 


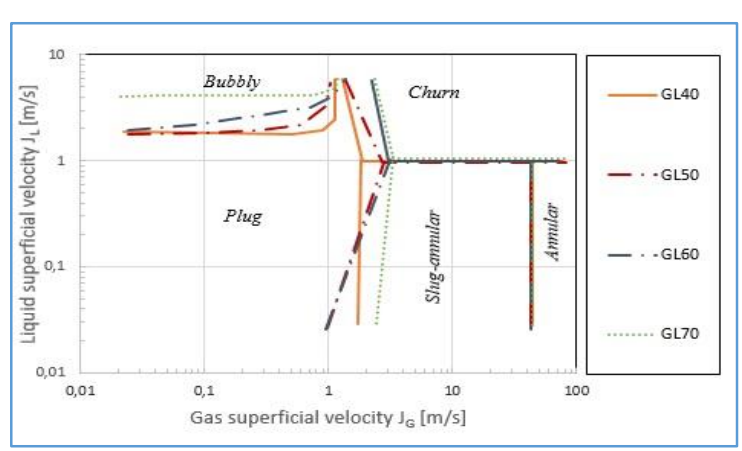

Gambar 2. Peta pola aliran udaraair+gliserin $40-70 \%$

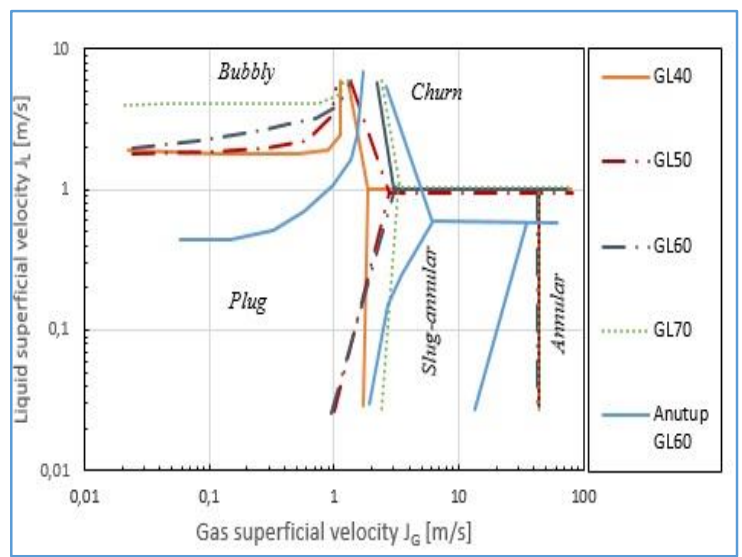

Gambar 3. Perbandingan peta pola aliran udara-air+40-70\% terhadap Anutup (2016)

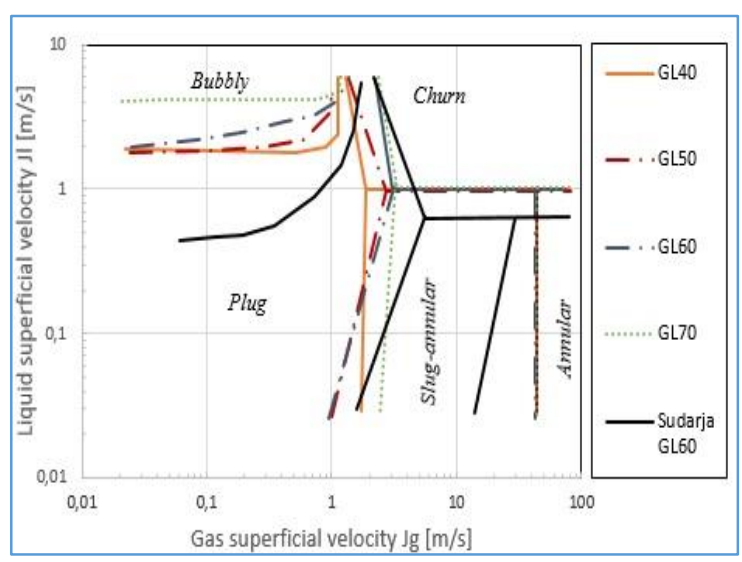

Gambar 4. Perbandingan peta pola aliran udara-air+40-70\% terhadap Sudarja (2018)

Sebelumnya, D. Anutup (2016) [11] telah melakukan penelitian tentang karakteristik pola aliran pada pipa mini 1,6 $\mathrm{mm}$ dengan variasi air gliserin dan udara (20\%, 40\%,dan 60\%). Pada penelitian ini pola aliran yang didapat yaitu bubbly, plug, slug-annular, annular dan churn. Dari hasil terlihat ada kesesuaian kecenderungan pola aliran yang terjadi walau terdapat pergeseran nilai $J_{G}$ dan $J_{L}$ seperti dapat dilihat pada Gambar 3. Penelitian sebelumnya juga pernah dilakukan oleh Sudarja dkk. (2018) [12] tentang aliran dua fase menggunakan pipa dengan diameter $1,6 \mathrm{~mm}$ yang dipasang secara horizontal. Media yang digunakan pada penelitian ini adalah udara dan air+gliserin dengan tujuan untuk mengetahui pengaruh viskositas terhadap terbentuknya pola aliran dua fase. Kecepatan superfisial gas pada penelitian ini adalah 0,008-64,42 $\mathrm{m} / \mathrm{s}$, sedangkan untuk kecepatan superfisial cairannya adalah 0,002-3,09 m/s. Dari hasil pengamatan yang dilakukan pola yang berhasil teramati adalah bubbly, plug, slug annular, annular, dan churn. Jika dibandingkan dengan penelitian sebelumnya yaitu Anutup (2016) dan Sudarja (2018) seperti ditunjukkan paa gambar 3 dan 4, area transisi aliran bubbly pada konsentrasi gliserin $70 \%$ terlihat memiliki luas yang jauh lebih kecil daripada konsentrasi $40 \%$ dan 50\%, namun hampir memiliki kesamaan luas dengan konsentrasi $60 \%$. Pergeseran garis transisi juga terjadi pada daerah slug-annular dan churn dimana setiap kenaikan konsentrasi gliserin garis transisi slug-annular dan churn semakin bergeser ke arah kanan. Sedangkan garis transisi pada daerah annular tidak mengalami perubahan posisi di setiap kenaikan konsentrasi gliserin.

\section{Kesimpulan}

Berdasarkan pembahasan tersebut di atas dapat disimpulkan bahwa kecepatan superfisial gas/cairan berpengaruh secara signifikan terhadap terbentuknya pola aliran. Disamping itu, viskositas juga memiliki pengaruh yang berarti terhadap tipe pola aliran yang terjadi. Namun jika dibandingkan antara kecepatan superfisial gas/cairan dan viskositas, maka kecepatan superfisial gas/cairan lebih dominan pengaruhnya terhadap terbentuknya jenis pola aliran yang terjadi. Artikel ini mempresentasikan lima jenis pola aliran yaitu plug, bubbly, slug annular, annular, dan churn. Hasil perbandingan peta pola aliran ini dengan penelitian terdahulu menunjukan hasil yang signifikan berbeda 
namun masih memiliki kecenderungan bentuk peta yang relatif sama, khususnya pada garis transisi pola aliran bubbly, slugannular dan churn.

\section{Ucapan Terima Kasih}

Kementerian Pendidikan Tinggi, Riset dan Teknologi Republik Indonesia melalui Skema Penelitian Dasar Unggulan Perguruan Tinggi (PDUPT) dan Jaka Sabiq $M$ yang telah membantu mengambil data.

\section{Referensi}

[1]. Fukano, T., \& Kariyasaki, A. (1993). Characteristics of gas-liquid two-phase flow in a capillary tube, 141, 59-68.

[2]. Triplett, K. A., Ghiaasiaan, S. M., Abdel-Khalik, S. I., \& Sadowski, D. L. (1999). Gasliquid two-phase flow in microchannels Part I: twophase flow patterns K.A., 25, 395-410.

[3]. Serizawa, A., Feng, Z., \& Kawara, Z. (2002). Two-phase flow in microchannels Akimi, 26, 703-714.

[4]. Kawahara, A., Chung, P.M.Y., Kawaji, $\quad$ M., 2002, Investigation of Two-Phase Flow Pattern, Void Fraction and Pressure Drop in a Microchannel, International Journal of Multiphase Flow, Vol. 28, pp. 1411-1435.

[5]. Chung, P. M. Y., \& Kawaji, M. (2004). The effect of channel diameter on adiabatic twophase flow characteristics in microchannels. International Journal of Multiphase Flow, 30(7-8 SPEC. ISS.), 735-761. https://doi.org/10.1016/j.ijmul tiphaseflow.2004.05.002

[6]. Wegmann, A. (2005). Multiphase Flows in Small Scale Pipes, (16189).
[7]. Biksono, D. (2006). Karakteristik dan Visualisasi Aliran Dua Fasa pada Pipa Spiral. Jurnal Teknik Mesin, 8(1), 69-74.

[8]. Sudarja, Indarto, Deendarlianto, and Aqli Haq (2016) Experimental study on the void fraction of air-water twophase flow in a horizontal circular minichannel. AIP Conference Proceedings 1737, 040014; https://doi.org/10.106 $3 / 1.4949302$

[9]. Wibowo, R., Hudaya, A. Z., \& Kabib, M. (2015). Studi Eksperimen Mengenai Sub-Sub Pola Aliran Stratified Pada Aliran Dua Fasa Searah Berdasar Fluktuasi Beda Tekanan Pada Pipa Horisontal, 6(2), 385390.

[10]. Wiryanta, I. K. E. H. (2015). Void Fraction Dan Pemetaan Pola Aliran Dua Fase (Air-Udara) Melewati Elbow $75^{\circ}$ Dari Pipa Vertikal Menuju Pipa Miring $15^{\circ}, 15(2), 82-89$.

[11]. Anutup D., (2016). Studi Visualisasi Pola Aliran dan Peta Pola Aliran Dua Fase UdaraAquades/Gliserin pada Saluran Mini Horizontal Berukuran $\quad 1,6 \quad \mathrm{~mm}$. Electronics Theses and Dissertations, Gadjah Mada University, 2016.

[12]. Sudarja, Jayadi, F., Indarto, Deendarlianto, \& Widyaparaga, A. (2018). The effect of liquid viscosity on the gas-liquid two-phase flow pattern in horizontal minichannel. AIP Conference Proceedings, 2001. 